\title{
Nuanses in die filosofie van die wetsidee
}

\author{
Author: \\ Helena Hoogstad ${ }^{1}$ \\ Affiliation: \\ ${ }^{1}$ Subject group Philosophy, \\ School of Basic Sciences, \\ North-West University, \\ Vaal Triangle Campus, \\ South Africa \\ Correspondence to: \\ Helena Hoogstad \\ Email: \\ helena.hoogstad@koers. \\ co.za \\ Postal address: \\ PO Box 1174, Vanderbijlpark \\ 1900, South Africa
}

How to cite this article:

Hoogstad, H., 2014, 'Nuanses

in die filosofie van die

wetsidee', Koers - Bulletin for

Christian Scholarship 79(3),

Art. \#2197, 2 pages. http://

dx.doi.org/10.4102/koers.

v79i3.2197

\section{Copyright:}

(C) 2014. The Authors.

Licensee: AOSIS

OpenJournals. This work

is licensed under the

Creative Commons

Attribution License.
Read online:
Dit is besonder aangenaam om hierdie spesiale uitgawe, getiteld Nuanses in die filosofie van die wetsidee, aan die Koers-lesers, die reformatoriese akademiese gemeenskap en vakwetenskapspraktisyns bekend te stel.

Hierdie uitgawe is georganiseer rondom Marinus Dirk Stafleu se gelyknamige artikel. Sy artikel lewer kommentaar op Danie Strauss se boek, Philosophy: Discipline of the disciplines (kyk Strauss 2009; Griffioen 2013; Cameron 2009). Laasgenoemde stimulerende werk, gepubliseer gedurende 2009, bied 'n kritiese ontwikkeling van Herman Dooyeweerd se filosofie van die wetsidee aan. In Stafleu se artikel lig hy die interpretatiewe verskille tussen sy eie, Strauss en Dooyeweerd se benadering tot die filosofie van die wetsidee uit en wys op die belang van artefakte en tegnologie in die verkenning en ontwikkeling van die reformatoriese projek.

In reaksie op 'n voorstel van Bruce Wearne, het Koers 'n aantal navorsers genooi om op Stafleu se artikel te reageer. In hierdie uitgawe word Andrew Basden, Maarten Verkerk en Danie Strauss se responsartikels gepubliseer.

Basden analiseer Stafleu se bespreking van artefakte differensieerbaar op grond van die aspek waarop die tegniese aktiwiteit gerig word. Dit word in sy artikel, Understanding artefacts related to human aspects: The case of information technology and systems, verwoord. Stafleu se bespreking word tot die ses premenslike aspekte beperk. In sy respons rig Basden sy aandag op die inligtings- en kommunikasietegnologie as ' $n$ artefak gerig op die menslike linguale aspek. Hy toon verder aan hoe Dooyeweerd se teorie van modale aspekte gebruik kan word om die inligtingstegnologie en rekenaarsisteme te bestudeer. Terselfdertyd word aangetoon dat hierdie studie ook 'n bydrae tot die verstaan en ontwikkeling van die Dooyeweerdiaanse filosofie kan lewer.

Verkerk se bydrae as filosoof én praktisyn bied erkenning aan sowel Stafleu as Strauss se werk en beklemtoon die belang van die beskikbaarheid van Christelike filosofiese konsepte vir die ontwerp van tegnologie. In The dual challenge of Christian philosophy: How to make philosophical ideas and concepts available for engineers?, gebruik Verkerk filosofiesgebaseerde konsepte as gereedskap om ingenieurspraktyk(e) te ondersteun.

In die vierde en laaste artikel van hierdie uitgawe, Systematic considerations within the philosophy of the cosmonomic idea, toon Danie Strauss aan dat heelwat van die verskille wat daar tussen homself en Stafleu skyn te wees as terminologieverskille verstaan kan word. Strauss lê klem op die waarde van Stafleu se noukeurige uitwerk van die spesifieke menslike vaardighede wat deur die verskillende modale aspekte gekenmerk word.

Hierdie uitgawe van Koers bied Stafleu se talle prikkelende en weldeurdagte insigte, sowel as die verdere akademiese ontwikkeling wat dit oproep. Dit bied egter nog meer: in hierdie uitgawe word Stafleu se betekenisvolle langtermynbydrae (Sien Bylaag 1) tot die Christelike reflektering in die vakwetenskappe sowel as in die filosofie ook gehuldig.

\section{Literatuurverwysings}

Cameron, A., 2012, 'Book review of: Philosophical frameworks for understanding information systems', Philosophia Reformata 77, 85-90.

Griffioen, S., 2012, 'Danie Strauss: Philosophy as discipline of disciplines', Koers - Bulletin for Christian Scholarship 77(2), Art. \#409, 3 pages. http://dx.doi.org/10.4102/koers.v77i2.409

Strauss, D.F.M., 2009, Philosophy: Disciplines of the disciplines, Padeia Press, Grand Rapids. 


\section{Bylaag 1 \\ 'Philosophical publications by Marinus Dirk Stafleu'}

1966, 'Quantumfysica en wijsbegeerte der wetsidee', Philosophia Reformata 31, 126-156.

1968, 'Individualiteit in de fysica', in D.M Bakker et al., Reflexies, opstellen aangeboden aan Prof. Dr. J.P.A. Mekkes, ter gelegenheid van zijn zeventigste verjaardag, pp. 287-305 Amsterdam: Buijten en Schipperheijn.

1970, 'Analysis of time in modern physics', Philosophia Reformata 35, 1-24; 119-131.

1972, 'Metric and measurement in physics', Philosophia Reformata 37, 42-57.

1978, 'The mathematical and technical opening up of a field of science', Philosophia Reformata 43, 18-37.

1979, 'The isolation of a field of science', Philosophia Reformata 44, 1-15.

1980, 'The opening up of a field of science by abstraction and synthesis', Philosophia Reformata 45, 47-76.

1980, Time and again, A systematic analysis of the foundations of physics, Wedge/Sacum, Bloemfontein/ Toronto.

1981-1982, 'Theories as logically qualified artefacts', Philosophia Reformata 46, 164-189; 47, 20-40.

1983-1984, 'Kritische studie: Popper's Postscript', Philosophia Reformata 48, 50-65; 49, 71-91.

1984 , 'The kind of motion we call heat', Tydskrif vir christelike wetenskap 20, 1-43.

1985 , 'Spatial things and kinematic events (On the reality of mathematically qualified structures of individuality)', Philosophia Reformata 50, 9-20.

1986, 'Some problems of time - some facts of life', Philosophia Reformata 51, 67-82.

1987, Theories at work, On the structure and functioning of theories in science, in particular during the Copernican revolution, Lanham, University Press of America, New York/London.

1988, 'Criteria for a law sphere (with special emphasis on the 'psychic' modal aspect)', Philosophia Reformata 53, 171-186.

1989, De verborgen structuur, Wijsgerige beschouwingen over natuurlijke structuren en hun samenhang, Buijten en Schipperheijn, Amsterdam.

1991, 'Being human in the cosmos', Philosophia Reformata 56, 101-131.

1992, En toch beweegt zij, Geschiedenis van de natuurkunde van Pythagoras tot Newton, Boom, Meppel etc.

1994, 'De structuur der materie in de wijsbegeerte van de wetsidee', in H.G. Geertsema et al. (eds.), Herman Dooyeweerd 1894-1977, Breedte en actualiteit van zijn filosofie, pp. 114-142, Kok, Kampen.

1995, 'The cosmochronological idea in natural science', in S. Griffioen, B.M. Balk (eds.), Christian philosophy at the close of the twentieth century, pp. 93-111, Kok, Kampen.

1995, 'Modelvorming als heuristisch instrument in het wetenschappelijke ontsluitingsproces', Philosophia Reformata 60, 1-15.

1996, 'Filosofie van de natuurwetenschap', in R. van Woudenberg (red.), Kennis en werkelijkheid, pp. 177-202, Buijten en Schipperheijn, Amsterdam.

1997, 'Comments on anticipations', Philosophia Reformata 62, 129-144.

1998, Experimentele filosofie, Geschiedenis van de natuurkunde vanuit een wijsgerig perspectief, Buijten en Schipperheijn, Amsterdam.

1999, 'The idea of natural law', Philosophia Reformata 64, 88-104.

2000, 'The idionomy of natural kinds and the biological concept of a species', Philosophia Reformata 65, 154-169.

2002, Een wereld vol relaties, Karakter en zin van natuurlijke dingen en processen, Buijten en Schipperheijn, Amsterdam. (translation: Stafleu 2006, part IV; Stafleu 2010).

2002, 'Evolution, history and the individual character of a person', Philosophia Reformata 67, 3-18.

2003, 'On aesthetically qualified characters and their mutual interlacements', Philosophia Reformata 68, 137-147.

2004, 'On the character of social communities, the state and the public domain', Philosophia Reformata 69, $125-139$.

2005, 'The relation frame of keeping company. Reply to Andrew Basden', Philosophia Reformata 70, 151-164.

2006, 'Infinity and continuity', Tydskrif vir Christelike Wetenskap, 163-174.

2006, Relations and characters in Protestant philosophy, from http://www.freewebs.com/stafleu

2007, 'Philosophical ethics and the so-called ethical aspect', Philosophia Reformata 72, 21-33.

2008, 'Isaac Newtons Philosophiae naturalis principia mathematica', Radix 34, 39-53.

2008, 'Time and history in the Philosophy of the Cosmonomic Idea', Philosophia Reformata 73, 154-169.

2010, A world full of relations, from http://www.scibd.com/doc/29057727 (pdf, translation of Stafleu 2002a).

2011, 'Bestaan driehoeken en cirkels echt?', Sophie 1(4), 44-47.

2011, Chronos \& Clio, De tijd in de geschiedenis, Buijten en Schipperheijn, Amsterdam.

2014, 'Nuances in the Philosophy of the Cosmonomic Idea', Koers - Bulletin for Christian Scholarship 79(3), Art. \#423, 8 pages. http://dx.doi. org/10.4102/koers.v79i3.423

2015, Acts, artefacts, and associations, A Christian social philosophy of ethics, history, and policy, to be published.

2015, Theory and experiment, Christian philosophy of science in a historical context, to be published. 